\title{
監視批判はなぜ困難か
}

——再帰的近代におけるリスク処理の形式としての監視——

\section{鈴木 謙介*}

「セキュリティの強化」と「監視」を巡る問題が近年になって特に注目され るようになったこここでいうセキュリテイの強化とは，単なる監視カメラの 設置による監視の氾濫を指すのではなく，予防的措置の極大化によって，あ るシステムにとってふさわしくない人間をあらかじめ排除するという動きの 全体を指している.

こうした監視の強化と排除に対して批判を加えることは一見容易に見える が実はそうではない，その理由は，監視を批判しょうとすることが監視によ って実現される価值への批判へとすり替えられていくからである。例えば監 視による排除が階層格差を前提にしている場合, それは格差批判にはなって も監視そのものを批判することはできないのだ.

本稿ではこうした監視批判の困難を乗り越えるために，どのようなシステ 厶作動によってセキュリティの強化が行われているのかを分析した。 その結 果明らかになったのは，監視を行うことそれ自体がマシンによるデー夕管理 の自動化によって監視対象を外部から不可視化する作用を持つこと，そして， そのような外部に対する不可視化がさらに内部に対して過剩な可視化を呼び 出し, 内部のロジックが一種の道徳律として機能するということだ. 監視批 判が困難なのは, この2方向の力の作動が存在するからだと考えられる.

キーワード：監視社会，リスク，セキュリティ

\section{1 はじめに}

「監視」と「セキュリティ」を巡る問題が我が国でも注目されるようになってき た. 監視自体は目新しいテーマではないが，「セキュリティの強化」，すなわち警 察権力の強化と治安維持（ポリシング）という，9.11テロ後のアメリカを中心と して拡大した事態が，この分野の主要なテーマだとみなされている。また日本の 場合はそれとは別に，イギリスに㧍ける監視カメラの増加などを前例として，犯 罪防止のためにテクノロジーを用いた監視を強化するべきだという主張と共に登 場した．特に 2003 年に長崎で起きた児童殺傷事件では，民間によって設置された カメラが事件解決に大きく役立ち，また犯行そのものもカメラの死角で起こった

\footnotetext{
*国際大学グローバル・コミュニケーション・センター
} 
ことが報じられたが，これが契機となってにわかに監視カメラ ${ }^{1)}$ 設置の是非が問 われることになった。

まず簡単に整理して抢くと,「セキュリティの強化」(ないし「セキュリティ化」) とは以下のような事態を指す。すなわち，犯罪のような社会的に有害だとみなさ れる振る舞いに対処していく方法として, 通常「〈予防〉と〈事後処理〉」(渋谷望 2003：179）のふたつが考えられるわけたが，そのうち前者を極大化させて，あら かじめ安全（セキュア）な状況を作り出す抑制策の拡大がそれである．後述する ようにこれは未来に向けられた対処方法であり，またそれゆえその処置が対象と するのは現在ではなく，未来の犯罪者，つまり犯罪者予備軍なのである.

このときに「予備軍」として誰を数え上げるかという問題が生じるわけだが, その数え上げを可能にするのが監視やバイオメトリクス（生体認証）をはじめと する種々の監視テクノロジーである。予防措置としてのセキュリティの強化は， テクノロジーによる人々の監視および管理の強化でもあるわけだが，「プライバシ 一の侵害」として括られるような様々な問題を孕むという批判がなされている.

しかしながら，ときに感情レベルで納得してしまいがちなこうした批判は，本 質的な意味でセキュリティの強化に対する批判たり得ないと筆者は考える．とい うのもこうした批判は基本的に監視の「是々非々」を巡って投げかけられている のであり，遺伝子診断はだめだが生体認証なら許容できる，監視カメラの設置は 容認できないが個人情報が特定されないような形での監視なら認められる，とい った具合に，納得できる範囲内での監視には賛成していると言えるからだ。

監視社会への批判は，監視が我々の「安全」の基盤となることを目指している がゆえに監視自体への批判へとつながりにくいという特徵を持つ，換言するなら， セキュリティの強化を批判しょうとすると，「監視批判」ではなく「監視の内容批 判」以外のロジックがあり得なくなり, 監視内容への価值的コミットメントを巡 る対立へと議論が回収されてしまうということだ.

重要なのは,「監視批判」と「監視の内容批判」の水準を峻別し,「監視批判」 を可能にする条件を探ることである，そこで本稿ではまずセキュリティの強化に 関わる種々の監視テクノロジーについて現状を確認し，それをもとに監視の本質， すなわち監視とは「何を」監視することであるのかについて分析する，その分析 を前提に, 監視の「何が」問題なのか, そして「なぜ」社会のセキュリティ化が 要請されているのかについて検討するのが, 本稿の目標設定である.

\section{2 監視と管理}

セキュリティの強化は, 種々の監視テクノロジーによって可能になると述べた が，具体的にはどのようなものが考えられるか.ここでは現在もっとも普及して いるであろうと思われる「監視カメラ」とそれ以外のテクノロジーを, 主として 警察などの公的権力によって設置されるものと, 民間によって設置されるものと 
に分け，その設置目的の違いに注目しながら見ていくことにする.

\section{1 公的権力による監視}

公権力によって設置される監視テクノロジーの代表例が監視カメラだが，大ま かに言って「自治体・警察が直接設置するもの」と「指導によって民間が設置す るもの」がある，警察が設置するものとして代表的なのは，警視庁が推進する 「街頭防犯カメラシステム」で，新宿区歌舞伎町などにカメラを設置しているもの だ．警視庁によるとこのシステムは「犯罪が発生するがい然性の極めて高い繁華 街等における犯罪の予防と被害の未然防止を図るため, 公共空間に防犯カメラを 設置し，撮影した映像を常時モニター画面に映し出し，これを録画するもの」だ という（警視庁 2003）。このシステムの運用方法としては，カメラに写った映像 をリアルタイムで監視する「モニター」，1週間分のデータを記録しておく「録画」， そして必要に応じて警察署長に対して「映像デー夕の提供」を行うことができる とされている。

これは警察が直接に設置したものだが，そのほかにも指導という形で設置され たカメラもある。例えばJR，東京都営地下鉄の各駅には，95年の地下鉄サリン事 件以降，防犯目的の監視カメラが設置されている（監視社会を拒否する会 2003）.

また，これ以外にも民間によって自主的に設置されるカメラも存在する．東京 都江戸川区新小岩の商店街に設置された監視カメラが報道などで有名になったが, 警視庁の委託研究による「コミュニティセキュリティカメラシステムに関する調 査研究報告書」によると，こうした民間の設置する監視カメラは現在コス卜面な どでの問題を抱えており，また人材の不足などからモニターを行うことが困難で あるため, 警察・警備会社との連携が必要であると指摘されている(警視庁 2001). 前述の歌舞伎町に扔ける監視カメラは，こうした取り組みのテストケースであり， また「東京都安全・安心まちづくり条例」の施行などによって，民間のカメラ設 置に対する補助金交付なども行われることになっている．以上のように，監視力 メラの設置を巡っては，設置主体がたとえ民間であっても，そのデー夕は警察な どに提供され利用されていくという傾向がある.

\section{2 民間による監視}

同時に，こうした官民一体の取り組みの他にも，主に民間によって開発された， カメラを用いないセキュリテイ強化策も登場している。その代表例が「生体認証」 だろう。生体認証とは，例えば屝の鍵の代わりに指紋や瞳の虹彩・網膜パターン などを用いるもので，現在，国土交通省が国際線のチェックインなどに導入実験 を行っており（国土交通省 2002），大阪では指先の血管のパターンを登録してお いて鍵として利用する「血流認証システム」を採用したマンションが登場した.

また，こうした生体認証のようなテクノロジーを駆使しなくとも，いまや「高 セキュリティ」を謳うマンションは多数登場している，その多くが都市部に建築 
されたものであり，警備員の巡回や監視カメラの設置，ピッキング被害を回避す るための電子キーの導入などを売り文句としている，さらに言えば，こうしたマ ンションの中には通常のマンションと異なり, エントランスにフロントが設けら れ，宅配便の受け取りからクリーニングの代行，DPEの受付など「ホテル並みの サービス」を提供する超高級マンションも数多く存在し, 高額な管理費用にもか かわらず企業経営者などのニーズを満たしている.

言ってみれば，こうした都心部の高級マンションはセータ・ロウ（Low 2003） やエドワード・ブレイクリーとマリー・スナイダー (Blakely and Snyder 1999) などが描くようなゲイテッド・コミュニティ，すなわち外部に対して門を閉ざし， コミュニティの中だけで安全に自足するような「要塞」の日本版 ${ }^{2 !}$ なである. 民間によって導入されるサービス全般に言えることだが，七キュリテイの強化は 「公共空間に㧍ける安全の確保」というよりはむしろ「安全を金で買う」という事 態なのである。

\section{3 監視の何が問題なのか}

以上のような監視を伴うセキュリティの強化に対しては，特にその設置目的に 関して様々な批判が寄せられている. 代表的な批判は「プライバシーの侵害」に 関わるものである，公共空間における監視カメラの設置に関しては，監視カメラ の作動が通行人に周知されないケースもあり, 肖像権の侵害に当たるという批判 が根強い.さらに踏み込んだ批判としては, 監視データの監用の危険が取りざた されている. 監視カメラのデータが無条件で警察に提供されている状況を問題視 し，防犯に用いられるはずのデータが「予防的措置」の名の下に様々な別の用途 に流用され，ひいては警察権力による思想・信条の取り締まりにつながるのでは ないかというのがその趣旨だ。この種の批判は, 監視そのものへの感情的な違和 感を表明するか，厳格な運用のガイドラインを制定せよという主張へと結実する.

また別の批判としては，選別と排除を巡る問題がある，治安維持のために個人 のプライバシー情報が蓄積, 利用されていくと, 犯罪の究極的な防止策である 「生まれる前」からの犯罪の可能性の除去, 寸なわち優生学を招来するというのが もっとも踏み込んだ主張だ。実際，ヒトゲノム解析プロジェクトは人間の遺伝子 情報の解読をほぼ完了させており, 出生前診断もかなりの程度で実用化が進んで いるという技術的な前提がそこには存在する。

そこまでいかなくとも，民間によって導入されるサービスがそうであるように 「持てる者」が「持たざる者」を排除する，ある領域において「ふさわしい者」と 「ふさわしくない者」を選別するようなセキュリティの強化は望ましくないという 批判が提出されている.

だが筆者は，こうした批判は監視とそれによるセキュリテイの強化そのものに 対する本質的な批判たり得ないと考える. 確かにゲイテッド・コミュニティを巡 る諸問題は，それが「持てる者による持たざる者の排除」である限りにおいて可 
視的なものとして主題化される。だがそれはこの空間的隔離が資本格差に結びつ けられているからこそ問題だと言いうるのであり，ときにカルチュラル・スタデ イーズの論者が用いるような「対抗的コミュニティ」を肯定するロジック ${ }^{3)}$ と一 体になる限りに扔いて，それは「監視批判」ではなく「格差批判」なのである.

濫用の危険についても同じことが当てはまる。警察権力による濫用を問題視す る場合には「監視」がただちに社会の警察化を呼び出すという極端な主張を取ら ない限りは，常に「どこまでの監視なら許容されるか」という是々非々を巡る問 題として取り扱われざるを得ない．むろん，具体的な政策決定の場面に㧍いては そうしたコミュニケーションが必要であろう。しかしながら監視の内容へと向け られた議論は必然的に「良い監視」と「悪い監視」の線引きになるのであって， 何を「良い」監視（とその前提となる価値）として奉じるかという問題へとすり 替えられていくことは否めない.

特に, 監視やセキュリティ化の内容を論じようとする場合に最も重要な困難と なって現れるのは，七キュリティ化への要望が民間の側から提出されているとい う事実だ．先の出生前診断がよい例だが，民間主導のセキュリティ化は公的領域 に㧍ける治安維持という目的ではなく，私的領域のコミュニケーションに㧍ける 幸福追求の問題として登場しているのだ。森岡正博は，そうした幸福追求の問題 点について倫理学的な指摘を行っている(森岡 2003). しかし繰り返すように, 何を「良いセキュリティ化」として定義するかが問題なのではない. 必要なのは， 「良いセキュリティ化」へと動機づけられていくことがどのようなシステム作動の 下で選択された振る舞いなのか，についての分析である．以下に続く節では，こ うした観点から社会のセキュリティ化について検討を試みることにする.

\section{3 監視社会とは何か}

\section{1 管理社会と監視}

近代社会と監視というテーマで真っ先に想起されるのはミシェル・フーコーだ ろう（Foucault $1975=1977 ）$ しかし，前節で挙げたようなテクノロジーを用い た監視を論じる際には「監視一規律訓練」というイメージだけでは語り尽くせな いというのがこの分野での議論の傾向だ。その際，いつも最初に参照されるのが ジル・ドゥルーズの「管理社会」という概念である（Deleuze $1990=1996)$. 管 理社会は，ある閉じられた環境から別の閉じられた環境へ人々が移動していくプ ロセスに拈いて, 訓練を通じて不断に規律化されていくという「規律社会」とは 異なり，個別化されたデー夕によって個人が管理される社会である.

規律訓練の帰結は服従＝主体化であったが，管理社会に扔いてはこうした「分 割不可能だった個人 (individus) は分割によってその性質を変化させる『可分性』 (dividuels)」となる（Deleuze 1990=1992: 296）。すなわち，個人が何者であっ てどこに所属しているのかという論点が後退し, 当該の状況においてある個人が 
どのようなデータを有しているかが焦点化されるのが管理社会である.

こうした問題を現代社会のテクノロジーとの関連で分析するのがデイビッド. ライアンである $($ Lyon $2001=2002)$ ，彼によると，管理社会の重要なポイントは 近代の「流動性（mobility）」と密接な関係にある。近代においては身体が常に移 動状態にあるわけだが，ある空間から別の空間へと移動し，社会関係を取り結ぶ 際には，身分証明書のような個人をアイデンティファイするものが必要になる $(\text { Lyon } 2001=2002: 140-1)^{4)}$. 近年のコンピュータテクノロジーの発達によって， 近代に特徴的だった「個人のデータの管理」は，「データベースへの個人情報の蓄 積」という形でよりいっそう推し進められることになる。例えばクレジットカー ドを持っているということは，世界中どこに行ってもその個人が「消費者」たる 資格を有することを示すと同時に，売り手にとっては，その個人が商品を購入す る資格を有しているかどうかを, 個人への審問ではなく信販会社のデータベース にアクセス寸ることによって確認できるようになる，ということなのだ.

「消費者」というのは管理社会に扔ける重要なファクターである。というのも規 律社会の作動とは, 学校から工場へと規律化された個人を送り込み, 冕脱した人 間を監獄において再規律化して再び工場へ投げ返すという「労働者＝生産者」の 再生産プロセスであるわけだが，管理社会における個人とは，あるサービスの受 益・消費に関わる行為者のことだからだそその意味で管理社会は，テクノロジー のみならず消費社会，すなわち生産よりも消費が個人にとって前景化する社会を 前提にしている.

\section{2 ポスト規律社会の監視}

こうした「ポスト規律権力社会」とでも呼びうる管理社会における監視が究極 的にはバイオメトリクスによる認証を呼び出すのは, データベースへの個人情報 の蓄積によって増大した流動性を最終審級において束ねるのが個人の身体である. その意味では, 虹彩認証のような SF的な事態それ自身は「ポストモダン」という よりは，ライアンが依拠するウルリッヒ・ベックやアンソニー・ギデンズの言う 「徹底された近代」のそれに近い（Beck et al. 1994=1997）. 実際, 渋谷や東浩紀 （東・大澤 2003）が指摘するように，個人のデー夕を集合的に管理するという発 想はフーコーにおいて「生権力」，すなわち「規律権力」とセットになった「生政 治」として既に概念化されている（Foucault 1976=1986）.

規律と管理が同じ近代のコインの裏表であるとして，では管理社会における監 視が, 規律訓練における監視とどのように異なるのかをもう少し整理しょう。前 節で述べたとおり，セキュリテイ強化のための監視は，プライバシーへの配慮と いう観点などから「カメラによる監視」すなわち視線による監視という手法を離 れつつある.カメラによる監視は，「24時間監視カメラ作動中」という通行人へ の告知と一体になる限りで, 監視者の存在/不在やデータの蓄積のいかんにかか わらず, 公共空間における人々の規律の内面化を促す, まさにパノプティコン的 
な監視である。しかしながら現在では, 監視カメラも「ドーム型」と呼ばれる, 一見してカメラとは判別できないような形状のものが主流になりつつあり，また 監視そのものも，ビデオカメラを使用しないようなものが開発されつつある.

たとえば 9.11 テ直後，アメリカでは空港に拀いてアラブ系の人々だけが入念 なセキュリティ・チェックを受けなければならなくなり，問題となった。しかし 現在では，こうした人種差別と取られかねない監視に代わって，ゲートを通過す る人間の体温や心拍数などから「疑わしい」人間を割り出すサーモグラフィーの ような監視装置が登場している。このようなサーモグラフィーはアジア圈におい ては，空港においてSARSの疑いのある人間を特定するために使用されるなどし ているが，この際に行われる監視は，監視者から見て被監視者がどういう個人で あるのかということが特定できないという点が重要だ.

これはいわば「プライバシーの侵害の可能性が低い」監視の形態であるわけだ が，それが具体的な個人を監視していないとするなら，一体何を監視しているの だろうか.この点がまさに管理社会における監視の本質に関わる問題を指し示し ている。すなわち監視されているのは個人ではなく，体温などの個人にまつわる 「デー夕」なのだ。データを監視するということは，個人の内面のような「質」に 関わる部分ではなく，数値化された個人の属性，すなわち「量」に関わる部分を 監視することである。

さらに，数值を監視し，データベースに蓄積することによって，監視はプライ バシーの問題を回避できるだけでなく, 監視のルーチンを自動化してコストを下 げることができるというメリットが生じる，規律社会から監視社会へのシフトに よって生じるのはつまり，「人による人の監視から，マシンによるデー夕の監視へ」 という，監視の主体と対象の移動なのである ${ }^{5)}$.

こうした監視はどのような帰結を導くか. 次節で詳細に検討するが，規律社会 との相違という論点で考えるならば，規律社会が主体の社会への参入（学校）再参入 (監獄) に関わるシステムだとすると，管理社会はデー夕の監視一蓄積と いうプロセスによって，あるシステム（とりわけ市場システム）にとって望まし くない個人を社会から排除一不可視化するシステムなのだと言っていい. 例えば ニューヨーク市に扔ける，「割れ密理論」に基づいた「コミュニティ・ポリシング」 は, 治安を脅かす要素（街頭の落書きなど）を芽の段階からつみ取ることによっ て, あたかもそうした要素がはじめから存在しなかったかのようなクリーンな公 共空間を作り出す (Kelling and Coles $1996=2004)$ ． ストリートからの売春婦の 排除や，ショッピングモールにおける浮浪者の排除なども同様である.

こうした事態は, 治安を維持する側の主体的な意志によって, 危険な要因を 「外側へ排除する」というよりは，むしろそのような要因の不可視化によって「内 側に向かってゲートを閉ざす」ようなものだと考えるのが適当であろう．管理社 会化の進展によるこうした不可視化は, 見えない場所へと追いやられた人々の参 入・再参入を阻むだけでなく，ゲートの内側にいる人間にとって，そのような 
「外部」が存在したこと自体をも忘却させるという帰結をもたらす。

このような事態が問題であることは明らかであるように思われる。だが，これ を問題化するのは実は非常な困難をともなう．というのも冒頭に述べたとおり， これが階層格差に結びつけられている場合には「格差問題」を可視化することは できるが，選別二排除による不可視化そのものは問題にできないからだ。さらに 言えば，こうした不可視化は公的権力によって一元的に行われているのではなく， むしろ民間における監視カメラの「自主的な」導入が示すように，プライベート に，そして多元的に行われているのだ.

結局監視を巡る問題は，排除・選別してよい対象を巡る価值的な闘争へと，そ の位相がズラされていくことになる．例えば子どもを持つ親にとって，子どもの 安全を脅かす対象は排除されても「良い」し，お金持ちにとって泥棒は排除され ても「良い」のである、バリー・グラスナーは，そこで求められる排除がそもそ もメディアによって謆られた過剩な不安であり，それゆえ公共政策の方向性が見 䛊られてしまうことを問題視する（Glassner $2000=2004 ）$.つまり「銃を乱射す る若者」に怯えるあまり，人々が危険な若者の排除に躍起になり，結果として銃 を規制するという選択が採られなくなるというのがグラスナーの主張だ.

グラスナーのような立場は，いわば監視の「良さ (goodness)」に対して公共的 な「善さ (justice)」を対置させるもので, 非常に古典的なものだと言える。しか し既に述べたような監視によって進行する不可視化とは, 公共的観点からの善さ のような外部的な価值の切り離しをこそ促進するのである。こうした状況下では たとえある人が公共的「善さ」を価值的に選択したと主張しても, それを他者か ら見たその人自身の「良さ」と区別するのは非常に困難である.

こうした監視の価值を巡る難題に取り組むために必要なのは, そもそも監視に よって成立する不可視化とは何であるのかを明確にすることではないか. 以上の ような問題意識から次節では, 危険が不可視化される社会が, どのような作動に よってその処理を可能にしているのかをシステム論的な観点から検討することに しよう.

\section{4 セキュリティ強化の要因}

\section{1 リスク社会と信頼の問題}

前節までに見たように，管理社会における監視が「不可視化」という排除の形 式を持つことに対して，その原理そのものを否定するのは大変に困難である。 そ こで本節ではこの「不可視化」によるセキュリティの強化がどのようなシステム 作動によって呼び出されるのかを分析するわけだが，その際に参考となるのは二 クラス・ルーマンのいう「複雑性の縮減」という概念だろう。

周知のようにルーマンは，環境に対する複雑性が縮減されたシステムこそが行 為の選択を可能にする条件だとみなした（Luhmann $1973=1990)$. 青天の霹靂の 
ようなテロや，予想だにしない状況での通り魔殺人など，それまで我々の社会が 想定していた可能性の範疇を遙かに越える事態が想起され，それに対処していか ねばならないとき, そうした可能性の切断，すなわち監視による排除という形で 複雑性の縮減作動が呼び出されるのだという説明には，一定の説得力があるだろ j.

ただし，なぜこうした形での排除が要請されるのかについてはまた別の説明を 必要とする. 重要なのは, 管理社会に扔けるデータベースへの情報の蓄積が, 未 来予測のために利用されるという点だ．生命保険などがよい例だが，ある個人が 保険に加入する資格を有するかどうかは，その個人に属するデータが，それまで に蓄積されたデータベースのデータと照らし合わせて「問題がない」ことを確認 した後に決定される．同じように管理社会における監視も，その個人が当該シス テムにとってセキュリティ上「問題がない」かどうかを，データベースへの照会 によってチェックしているわけだ.

むろんこうした予測はあくまでそれまでに蓄積されたデー夕に基づく予測であ り, 確定された未来の出来事ではない. 健康な人が突然死することも, 抢となし い子が突如キレてナイフを振り回すことも，実際には起こりうる，にもかかわら ずこうした予測が成り立つと考えられるのは, 監視が単なる危険の予測ではなく, 「リスク」の予測に関わっているからである。

リスクを定義することは大変に困難な作業を伴うので，ここではリスクをべッ クに従って「未だ生じてはいないが既に脅威の対象となっている」未来の時点に おける不確定な危険としておく（Beck 1986＝1998：46）。こうした「将来起こる かもしれない」危険を予測して現在の行動を決定することは，現在ある偶発性に 対処するのとは別様の, 複雑性に対する縮減の形式を必要とする.

一般性を高めるために図式化して説明しょう．いま，ある未来の時点 $\mathrm{t}_{\mathrm{a}}$ に扔け る危険 Dが想定されているとする。この危険は，それによって被害を被るシステ ムにとって, 危険を除去し, 安全 Scへと変換したい対象である.しかし未来の時 点に扔ける出来事を選択し確定することは困難であるので， $\mathrm{D}$ は現在の時点 $\mathrm{t}_{1}$ に 打いて想定されるリスク Rとして処理されなければならない.リスクを算定する 振る舞いとは，こうした未来の危険を現在のリスクへと縮減する行為であるわけ だが，リスクに対する処理はあくまでも現在における選択であり，未来を確定す る行為ではない，言ってみればリスクに対する処理は常に，現在における安心 $\mathrm{Sf}$ の裏側に，未来において期待はずれに直面する不安 Aを抱えているのである。こ の不安は，リスクを算定し処理しようとすればするほど，システムに対するさら なる不安として現れてこざるを得ない。

ギデンズの言う再帰的近代とは，こうした不安を近代に特有のものと捉えた上 で，不安への対処が自己準拠するという強迫衝動的な事態を指している（Beck et al. 1994=1997: 106-204).つまり，いつまでたっても不安が解消されないので, たゆまざるリスク処理へと人々が動機づけられていくということだ。こうした事 


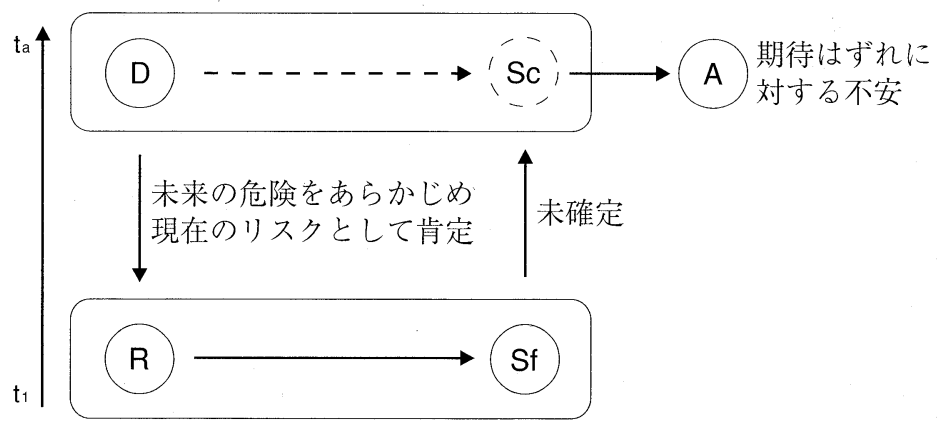

図 1 末来の危険の縮減と不安

態に対しベックは，未来に対する不確定さがリスクとして顕在化することによっ て，人々が不確定な未来への投企に動機づけられ，行動の指針を決定しうるよう になると主張していた。それが産業社会における階級対立から，世界リスク社会 における階級を越えたサブ政治の連帯を導くというのがベックの結論だったが， 管理社会における監視が実際に導いているのは，未来の不確定な危険の排除二不 可視化であり，サブ政治間の相互不可視化という事態なのである。そしてこの不 可視化を支えるのがテクノロジーの導入による，リスク処理のマシンによる自動 化なのだ。すなわち管理社会に扔けるデータの監視とは，いつまでたっても解消 しない強迫衝動的不安を，「不可視化」の処理によって切断することを可能にする 技術なのである。

\section{2 内的に道徳化する社会}

こうした「不安の不可視化=リスクの不可視化」は，その概念の出自とは裏腹 に，現実にはルーマン/ベックの考えるような事態とは対極に位置すると言える だろう．というのも「信頼」や「リスク」といった概念は，流動性や不確定性が 上昇した近代に扔いて，不確定であるにもかかわらずコミュニケーションの接続 へと結びつけられる人々の行為の「条件」として考えられていたが，ここまで見 てきたようにコミュニケーションはむしろ切断されているからだ。

これは山岸俊男の言う「安心社会」に近い状態だとみなすことができる（山岸 1999). 山岸によれば, 社会的ジレンマ状況に扔ける日米での行動決定の差は, ア メリカに扔いては「不確定であるにもかかわらず他者を信頼する」傾向があるの に対し，日本に拉いては見ず知らずの他者とのジレンマ状況にあたって，容易に 裏切り行為に出る傾向が強い. この差を山岸は不確定性に対する対処の形式の差 として分析する。すなわちアメリカ型の社会は不確定な状況に対して，一般化さ れた他者への信頼を媒介とした行為選択を行う「信頼社会」だが，日本型の社会 は，あらかじめ不確定な要素を排した内輪の関係の中でコミュニケーションを閉 
ざそうとする「安心社会」だというのだ.

これはいわゆる日米文化比較論というよりは社会工学的な「行為に先行する条 件設定」の問題だが，山岸はさらに，安心社会の「安心」を維持する条件として 「監視」が存在することを指摘している（山岸 1999：45-9）。これは誰かに見られ ていると思われる状況下では裏切りを控えるという意味で規律社会に打ける監視 に近いが，規律社会の監視が抽象化された水準からのそれであるのに対し，安心 社会に扔ける監視は具体的な他者からの視線である点が異なる。そうでなければ 山岸の実験において，監視が存在しないと分かったとたんに被験者が裏切り行為 に走る理由が説明できないわけだが，これが本稿で問題にしてきたような管理社 会における監視を分析するのに非常に役に立つ.

すなわち, ベックが想定しているような社会のあり方が「信頼社会」だとする と, 監視とリスク算定のテクノロジーによって不確定な要因が不可視化されてい く社会は，「安心社会」の乱立する社会だとみなすことができる，というのも，監 視による不可視化の作用は社会全体を包み込むようなレベルではなく，例えばニ ューヨークという地理的・行政的範囲で，あるいは強固なセキュリティに守られ たゲイテッド・コミュニティの内部で，という風に限定された範囲で通用しさえ すればよいからだ。監視社会化はプライベートかつ多元的に進行すると前に述べ た.つまり複数の監視社会が異なる価值を奉じ，それ以外の価值を不可視化して いるような状況こそが, 監視社会化の本質なのではないか.

監視社会が外部を不可視化していくときに，その内部にはいつも中心となって 奉じられる「良さ」が存在する。それは例えば「子供の安全の確保は何ものにも 優先する」といった価値だ。こうした価値をリスクの低い状態で維持するために は，監視社会の内部は外部の不可視化と同時に内部の過剩な可視化を呼び出さな ければならない.山岸の言う安心社会モデルに拈ける相互監視は, 外部が不可視 化されたことによって生じた内部への過剩な視線だと見てよい. そしてその相互 監視の視線は，監視社会が中心に奉じる価值を一種の道徳として，それに従わな い者を非難あるいは排除する方向に作動する．本来は住民以外の人間の侵入を防 ぐために導入されるマンションの監視カメラが，住民のゴミ出しをチェックする のにも利用されていくといった事態がその具体的な例となろう.

前述したような民間レベルでの監視の導入による「私的幸福の追求」と，こう した道德の公準として監視を利用するという振る舞いは一見矛盾しているように 思える。が，そこには以下のような共通のシステム作動があるとみなすべきだろ う。すなわち監視批判に対する「私的幸福」や「道徳」をよりどころにした反論 とは，外部に存在する不安の不可視化処理によって可能になったシステムの境界 を維持するためのローカルな価值の表明であり，そのことによって外部に存在す る「別様の選択の可能性」へのコミットを封鎖する機能を有しているのである.

以上から, 前節での「監視が外部の価值を不可視化していく作動とはいかなる ものか」という問いに対する回答が導き出せる。すなわち管理社会における監視 
は，ゲートの外側に対してはリスクの不可視化を促す「外向きの力」を持つと同 時に, ゲートの内側に対して, 切り縮められた不確定性を維持するための「内向 きの力」を有しているのである.ゆえに「切り縮められた外部」を可視化するよ うな,つまりあるシステムが対峙しているリスクを明らかにするような監視批判 や, 公共的な「善さ」の観点からの私的な「良さ」への非難は, 内向きの力に対 する脅威と理解され，システム内的価值の表明によって反論を封鎖せざるを得な くなってしまうのだ。言い換えれば，監視を強化していく社会は同時に「内的に 道德化する社会」でもあるのだということになる。

\section{5 おわりに}

これまでの筆者の主張をまとめよう，現代社会に広がりつつある種々の監視は， 規律社会における「人に対する，人による監視」とは異なり，「マシンによるデー 夕の監視」を行う管理社会のそれである。こうした監視は往々にして, ある権力 による選別＝排除を呼び出すがゆえに問題だとみなされるが，実際にはそれは排 除する側とされる側の格差を前提にした批判であり, 監視そのものに対する批判 ではない.これはその格差を解消してしまえば監視そのものに対する批判は困難 になるということである.

本稿で取り扱ってきた分析は，ポリティカル・イシューとしての「監視の是々 非々論」を離れても, セキュリテイ化のための監視を批判するロジックがあり得 るかを考察するために行われた。そこで，なぜ監視批判は困難であるのか，つま りセキュリティ化への反論の封じ込めがなぜ生じるのかを明らかにするために， そもそもなぜ監視が要求されるのかを分析するという戦略が採用された。すなわ ち管理社会における監視は, 一方で再帰的近代における外部のリスク処理にまっ わる不安を不可視化する機能と，他方で内部の価值的まとまりを強化する機能と いう 2 方向の機能を有しており,これらの機能が車の両輪となって監視の内部／ 外部の差異を強化していくようなシステム作動であるのだ。こうした監視の社会 システム理論的分析の視角を持ち込まない限り，監視批判は監視の帰結に対する 倫理的・感情的レベルでの違和感をよりどころにするか，監視によって生じる別 の問題を批判するという水準にとどまらざるを得ない.

筆者の取り組みはこうした水準にとどまらない監視批判を析出するという試み であったわけだが，今回は「なぜ監視批判は困難か」という分析にとどまり，監 視そのものの批判を導くロジックの検討にまでは至らなかった。とはいえ，こう した分析視角を提供することは，後に続く監視を巡る実証的・理論的取り組みに 対していくばくかの貢献をなし得るものであると考える.

今後の筆者の検討課題は, 引き続き監視批判の可能性を探ることにあるが, 既 にこうした取り組みは重大な困難に直面している。というのも監視による「不可 視化／道徳化」という2 方向の力は，拙稿で述べたようなリベラリズムの理論的 
後退, すなわ主遍妥当性要求を諦め, 限定された文脈での自由・平等の可能性 を検討する方向にシフトしつつあるリベラリズム論の世界的な地殼変動とリンク していると考えられるからだ（鈴木 2003）。つまり公的な「善さ」を不可視化し て, 私的な「良さ」の追求を可能にする監視社会のシステム作動が, その具体的 な現れになるということである。こうした前提に基づいて監視批判の領野に分け 入ることは, 単なる監視批判を越えてリベラリズムの本質論にまで切り込まなけ ればならない，その意味で必要とされているのは，具体的な監視状況の検討より もむしろ，そうした監視を支えるロジックの理論的な検討なのである. 以後の研 究においては，今回扱うことのできなかったリベラリズムとの関係においてより 一層の理論的分析を課題としたい.

\section{[注]}

1）特にカメラの設置に対して積極的な主張をする場合には，その利用目的を正しく表現するべ

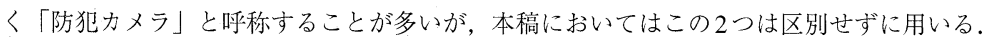

2）アメリカのゲイテッド・コミュニティは，ブレイクリーとスナイダー (Blakely and Snyder

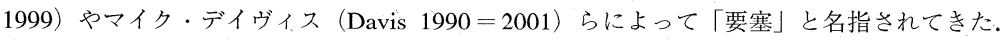

3）例えば渋谷望が述べるような黒人たちのコミュニティ（渋谷 2003：217-38）.

4）ルーマンが「信頼」という概念を呼び出す時，そこには「慣れ親しみの関倸」ではない関係 が要求される契機としての流動性の増大があったことを想起せよ（Luhmann 1973）。

5）拙稿でも述へたと扔り，企業に扔ける従業員のメール監視ソフトウェアは，人によるメール の内容チェックというコストを切り下げるために，キーワード登録による監視の自動化を実現 する機能を実装している(鈴木 2004).

\section{[文献]}

東浩紀・大澤真幸，2003，『自由を考える-9・11 以降の現代思想』NHK出版.

Beck, Ulrich, 1986, Risikogesellschaft: Auf dem Weg in eine andere Moderne, Frankfurt: Suhrkamp Verlag. (=1998, 東廉・伊藤美登里訳『危険社会一一新しい近代への道』法政大学出版局.)

Beck, Ulrich, Anthony Giddens and Scott Lash, 1994, Reflexive Modernization: Politics, Tradition and Aesthetics in the Modern Social Order, Cambridge: Polity Press. (=1997, 小幡正敏訳『再帰的 近代化一一近現代における政治，伝統，美的原理』而立書房.)

Blakely, Edward J. and Mary Gail Snyder, 1999, Fortress America: Gated Community in the United States, Washington D.C.: Brookings.

Deleuze, Gilles, 1990, Pourparlers, Paris: Éd. de Minuit.（=1996，宮林寛訳『記号と事件—1972-1990 年の対話』河出書房新社.)

Davis, Mike, 1990, City of Quartz, London and New York: Verso. (=2001, 村山敏勝 · 日比野啓訳 『要塞都市LA』青土社.)

Foucault, Michel, 1975, Surveiller et punir, Paris: Gallimard.（=1977，田村俶訳『監獄の誕生一一監 視と処罰』新潮社.)

——, 1976, La volonté de savoir, Paris: Gallimard. (=1986, 渡辺守章訳『性の歴史 I 知への 意志』新潮社.)

Glassner, Barry, 2000, The Culture of Fear: Why Americans Are Afraid of the Wrong Things, New York: Basic Books. (=2004, 松本薰訳『アメリカは恐怖に踊る』草思社.)

監視社会を拒否する会, 2003,「『NO！監視』ニュース【第4号】」(http://www009.upp.so- 
net.ne.jp/kansi-no/news/documents/news_2003_004.htm, 2003.11.15)

警視庁，2001，「コミュニティセキュリティカメラシステムに関する調査研究報告書」(http: //www.keishicho.metro.tokyo.jp/seian/kamera/image/chousa.pdf, 2004.1.19)

—，2003，「街頭防犯カメラシステム」(http://www.keishicho.metro.tokyo.jp/seian/ gaitoukamera/gaitoukamera.htm, 2004.1.19)

Kelling, George L. and Catherine M. Coles, 1996, Fixing Broken Windows: Restoring Order and Reducing Crime in Our Communities, New York: Simon \& Schuster. $(=2004$, 小宮信夫監訳 『割れ空理論による犯罪防止——コミュニティの安全をどう確保するか』文化書房博文社.)

国土交通省，2002，「e－チェックイン実証実験の実施について」. (http://www.mlit.go.jp/kisha/ kisha02/01/011105_.html, 2004.1.16)

Luhmann, Niklas, 1973, Vertrauen: Vertrauen. Ein Mechanismus der Reduktion sozialer Komplexität,

Stuttgart: Ferdinand Enke. (=1990, 大庭健 ·正村俊之訳『信頼一一社会的な複雑性の縮隇义 カニズム』勁草書房.)

Lyon, David, 2001, Surveillance Society: Monitoring Everyday Life, Buckingham: Open University Press. (=2002, 河村一郎訳『監視社会』青土社.)

Low, Setha, 2003, Behind the Gates: Life, Security, and the Persuit of Happiness in Fortress America,

New York: Routledge.

森岡正博, 2003, 『無痛文明論』トランスビュー.

渋谷望, 2003,『魂の労働——ネオリベラリズムの権力論』青土社.

鈴木謙介, 2003,「政治理論に対するグローバリゼーションの二局面— 90 年代以降の政治理論に 内在する困難とその要因の構造」『ソシオロゴス』27: 17-31.

一一, 2004,「その先のインターネット社会」宮台真司・鈴木弘輝編『二一世紀の現実（リア

リティ）—社会学の挑戦』ミネルヴァ書房.

山岸俊男, 1999, 『安心社会から信頼社会へ』中央公論新社.

(原稿受付 2004.7.11 掲載決定2004.11.17)

\title{
Why Is It Difficult to Criticize Surveillance? Surveillance as a Form of Risk Handling in Reflexive Modernity
}

\author{
SUZUKI, Kensuke \\ Center for Global Communication, International University of Japan \\ ksuzuki@glocom.ac.jp
}

Surveillance as a theme of this paper is what is attracting attention recently. Security strengthened by surveillance is not a proliferation of monitoring systems, but is a move towards prevention and exclusion of people who are not suitable for this system. The various technologies for surveillance enable watchpersons to exclude them. For example, there is not only a surveillance camera but also biometrics technology for authentication systems.

Although we normally tend to think it easy to criticize such technology, it is not 
true. This is because the criticism of surveillance is tacitly replaced by the criticism of values which are realized by surveillance. For example, the problem is not surveillance but an economic gap if the exclusion is based on the economic gap.

This paper aims to clarify why it is difficult to criticize surveillance. It uses "risk" and "reflexive modernity" as important concepts. Some arguments explain that accumulation of data based on surveillance is enabled to calculate a risk. Therefore, risk means a danger of the undecided future in this paper, and surveillance make us to be a decided one. But the "decided" future is always provisional. Accordingly, uneasiness always influences how danger is determined. This uneasiness is reflex.

According to Ulrich Beck, such reflexive uneasiness calls for people's solidarity among sub-politics in the worldwide risk society, although today it is characterized by inter-invisibilization among sub-politics.

This paper explains the mechanism of this invisibilization and points out the problems in the criticism of surveillance.

Key words: surveillance, risk, security

(Received July 11, 2004/ Accepted November 17, 2004) 